\title{
Population Density of the Mona Monkeys (Cercopithecus mona, Schreber, 1774) in Afi Mountain Wildlife Sanctuary, Cross River State, Nigeria
}

\author{
Bukie James Oshita ${ }^{1}$, Nchor Ayuk Atim ${ }^{2,}$, , Ebu Vincent Tawo ${ }^{2}$, Mgbang Edward Ubua ${ }^{2}$ \\ ${ }^{1}$ Department of Wildlife and Range Management, University of Agriculture, Makurdi, Nigeria \\ ${ }^{2}$ Department of Forestry and Wildlife Resources Management, University of Calabar, Calabar, Nigeria
}

Email address:

nchorayuk@yahoo.com (N. A. Atim)

${ }^{*}$ Corresponding author

\section{To cite this article:}

Bukie James Oshita, Nchor Ayuk Atim, Ebu Vincent Tawo, Mgbang Edward Ubua. Population Density of the Mona Monkeys (Cercopithecus mona, Schreber, 1774) in Afi Mountain Wildlife Sanctuary, Cross River State, Nigeria. Agriculture, Forestry and Fisheries.

Vol. 5, No. 6, 2016, pp. 261-265. doi: 10.11648/j.aff.20160506.17

Received: June 20, 2016; Accepted: July 4, 2016; Published: December 29, 2016

\begin{abstract}
A survey of Mona Monkeys (Cercopithecus mona) in Afi Mountain Wildlife Sanctuary, Cross River State, Nigeria, was conducted to determine its status, ecology and population density. Line transect method of wildlife population determination was adopted, and to assess the vegetation composition of the study area, the Total Enumeration Count of vegetation sampling was used. Two censuses were carried out in each of the ten transects ( $2.0 \mathrm{~km}$ length, $0.02 \mathrm{~km}$ width) and at interval of $1.0 \mathrm{~km}$ randomly selected. Direct method of animal sighting was employed. Mean population density of mona Monkeys in Afi Mountain Wildlife Sanctuary was $4 / \mathrm{km}^{2}$, implying that the species was sighted during the survey while the vegetation assessment revealed the study area to composed of tropical rainforest plants species though seriously modified through human activities.
\end{abstract}

Keywords: Mona Monkey, Population Density, Line Transect, Two Censuses, Direct Animal Sighting

\section{Introduction}

The rainforest of Cross River State is one of the richest in species diversity and endemism in the world, and it is home to two endemic and endangered primates, the Cross River Gorilla (Gorilla gorilla diehli) and the Drill monkey (Mandrillus leucophaus) [1]. Although some studies such as [2] have opined that the Mona Monkey is an ecological generalist, there is no record of previous surveys of Mona monkeys in the study area. This reason motivated this survey to ascertain this species ecology and population density in this species rich study area.

The quality of a habitat can be determined by the presence or absence of certain species of wildlife [3]. Primates are important indicator species because; these species are visible, often threatened, and endangered, have great public appeal and can be sensitive indicators of low-level disturbance [4].

According to [5], if there is a full complement of primate species present and at high population density then the forest habitat is providing the require resources and hunting is not excessive. However, if some species are missing or population densities are depressed, then adverse conditions are affecting primates and probably other wildlife as well.

The Mona monkey (Cercopithecus mona) is one of the Africa's most common guenon [2]. Though the species is protected by the Nigeria endangered species decree number 11 of 1985, it is conserved and protected only in National Parks, Games Reserves and Wildlife Sanctuaries.No record is available of previous survey of the mona Monkey in Afi Mountain Wildlife Sanctuary despite it ecotourism potentials. Mona Monkeys have few wildlife species that are involved in food competition and no predators from the wild. However, they are always facing the major anthropogenic threat of persistent and intensive hunting by poachers. Over the years, these species of primates have been subjected to severe hunting for bushmeat. Most times, adult monkeys are hunted for the purpose of using the young ones as pets. The ecological consequences of these threats are far-reaching; 
disrupting ecological functions over large areas and in key ecosystems. The extent of hunting in the study area in recent times is likely leading to local extirpation of many species of primates and mammals in the Sanctuary. Furthermore, the primate population recently faced a natural disaster through landslides and heavy flooding which devastated most of the forests around the area. It is therefore pertinent to embark on a post-demographic assessment of the remaining population of primate so as to establish their current status. This study is therefore aimed at assessing the population density of Mona Monkeys in Afi Mountain Wildlife Sanctuary.

\section{Materials and Methods}

\subsection{Study Area}

Afi Mountain Wildlife Sanctuary is in Boki Local Government Area of Cross River State, Nigeria. Geographically, it lies between Latitude $6^{\circ} 25^{\prime}$ and $6^{\circ} 30^{\prime}$ North and Longitude $8^{\circ} 45^{\prime}$ and $9^{\circ} 15^{\prime}$ East. The sanctuary is approximately $100 \mathrm{~km}^{2}$ in size and made up of rocks. It was created from the Afi River Forest Reserve in year 2000 following renewed international interest to protect the endangered Cross River Gorilla and the Drill Monkeys. It is located within the confines of host communities including Bounchor, Olum, Ndemechang, Esekwe, Bitiah, Kakabyom, Nkunyor, Kakabok, Njua kaku, Boje and Katabang, the climate of the study area is characterized by an extreme rainfall pattern of 3500 - above with mean temperatures of $27^{\circ} \mathrm{C}$ and Relative humidity of about $65 \%$ during the afternoons throughout the year. It is the sole water shed of the sixteen surrounding communities.

\subsection{Data Collection}

The Line transect method was used for the population estimate and status of the mona monkey as stipulated by [4], and used by [6]. Ten transects (two from each of the five blocks mapped out by [1], were randomly selected from the study area. Transect length of $2.0 \mathrm{~km}$ and width of $0.02 \mathrm{~km}$ and systematically spaced approximately $1.0 \mathrm{~km}$ from each other in accordance with the guidelines of [7]. Distances along transects were marked with flagging tapes at intervals of $0.5 \mathrm{~km}$ for easy identification of animal locations on transects. Each transect was covered by an observer and census was done simultaneously in all the ten transect selected, with the use of an electronic stop watch, which each observer had. This was done to reduce the incidence of double counting. The census started simultaneously at an agreed time, $(10: 00 \mathrm{hrs})$, date and pace $(1 \mathrm{~km} / \mathrm{hr})$. During the census, each observer was equipped with a binocular for easy observation and field notebook to record the following information:

1. Transect number.

2. Approximate right angle distance to the path of observation walked by observer.

3. Approximate distance of observer to animal sighted.

4. Number of Mona monkeys sighted.
Using the information above, the population density of Mona monkeys was determined using the formula:

$$
\mathrm{D}=\frac{\mathrm{N}}{2 \mathrm{LW}}
$$

Where:

$\mathrm{D}=$ animal population density (Number $/ \mathrm{Km}^{2}$ )

$\mathrm{N}=$ number of animals sighted

$\mathrm{L}=$ distance walked by observer $(\mathrm{Km})$

Ten (10) individuals conducted simultaneous surveys in the five blocks of Afi Mountain Wildlife Sanctuary in 2012. Officers and Rangers of Afi Mountain Wildlife Sanctuary were engaged in the surveys.

The Total Enumeration Count was used in determining the vegetation composition of the study area as described by [8] and used by [9]. This involved the establishment of $25 \mathrm{~m} \mathrm{x}$ $25 \mathrm{~m}$ plots or quadrants and all plants of $1 \mathrm{~m}$ and above in height and diameter of not less than $10 \mathrm{~cm}$ being enumerated. In this study, 20 plots or quadrants were sampled, 4 from each block. All tree plants above $1 \mathrm{~m}$ in height, with diameter of not less than $10 \mathrm{~cm}$ were enumerated. Data collected in each quadrant were: Total counting of all tree plants above $1 \mathrm{~m}$ height and diameter $\geq 10 \mathrm{~cm}$ and total enumeration of each plant species which were classified according to their families.

Plant density was therefore calculated as:

$$
\text { Plant Density }=\frac{\text { Total Number of Trees Counted }}{\text { Total Area Sampled }} \times 100
$$

\subsection{Data Analysis}

The student' 't'-test (test of independent means) was used to test the results of Mona Monkey population densities in the two censuses. The test criterion is given as:

$$
' \mathrm{t}^{\prime}=\frac{\left|\mathrm{x}_{1}-\mathrm{x}_{2}\right|}{\sqrt{\mathrm{sp}^{2}\left(\frac{1}{\mathrm{n}_{1}}+\frac{1}{\mathrm{n}_{2}}\right)}}
$$

Where;

$x_{1}=$ Density of first census

$x_{2}=$ Density of second census

$\mathrm{Sp}^{2}=$ Pooled variance

$n_{1}=$ Frequency of sight in first census

$n_{2}=$ Frequency of sight in second census

Pooled variance $\mathrm{Sp}^{2}=$

$$
\frac{\left[\sum \mathrm{x}_{1}^{2}-\frac{\left(\sum \mathrm{x}_{1}\right)^{2}}{\mathrm{n}_{1}}\right]+\left[\sum \mathrm{x}_{2}^{2}-\frac{\left(\sum \mathrm{x}_{2}\right)^{2}}{\mathrm{n}_{2}}\right]}{\left(\mathrm{n}_{1}-1\right)+\left(\mathrm{n}_{2}-1\right)}
$$

Or

$$
\frac{\left(n_{1}-1\right) S_{1}^{2}+\left(n_{2}-1\right) S_{2}^{2}}{\left(n_{1}-1\right)+\left(n_{2}-1\right)}
$$

Where;

$S_{1}^{2}$ and $S_{2}^{2}$ are variances for the first and second censuses respectively. The statement of hypothesis (in the null form) showed that there is no significant difference in the densities 
of the two censuses while results on plants species composition were analyzed as follows:

The Basal Area (BA) per tree was calculated using the expression:

$$
\mathrm{BA}=\frac{\pi \mathrm{D}^{2}}{4} \times 0.0001
$$

Where:

$\mathrm{D}=$ Mean Diameter at Breast Height $(\mathrm{cm})$
$\mathrm{BA}=$ Basal Area $\left(\mathrm{m}^{2}\right)$

While the Basal Area for each plot was expressed as:

$$
\mathrm{BAP}=\sum_{i=1}^{\mathrm{k}} \mathrm{BA}
$$

Where BAP $=$ Basal Area per plot

$\sum_{i=1}^{k} B A=$ Summation of basal areas of all trees and plants above $1 \mathrm{~m}$ height within sampled plots.

\section{Results}

\begin{tabular}{|c|c|c|c|c|}
\hline Transect Number & $\begin{array}{l}\text { Right angled distance by } \\
\text { observer, L(km) }\end{array}$ & $\begin{array}{l}\text { Effective walked strip } \\
\text { width, W(km) }\end{array}$ & Number of Monkeys sighted, $N$ & Animal Population Density \\
\hline 1 & 2.0 & 0.00 & 0 & 0 \\
\hline 2 & 2.0 & 0.00 & 0 & 0 \\
\hline 3 & 2.0 & 0.00 & 0 & 0 \\
\hline 4 & 2.0 & 0.00 & 0 & 0 \\
\hline 5 & 2.0 & 0.00 & 0 & 0 \\
\hline 6 & 2.0 & 0.00 & 0 & 0 \\
\hline 7 & 2.0 & 0.00 & 0 & 0 \\
\hline 8 & 1.9 & 0.15 & 20 & 35 \\
\hline 9 & 2.0 & 0.00 & 0 & 0 \\
\hline 10 & 2.0 & 0.00 & 0 & 0 \\
\hline
\end{tabular}

Table 1. Population Density of the Mona Monkeys in the First Census.

Population density $=4 / \mathrm{km}^{2}$

\begin{tabular}{|c|c|c|c|c|}
\hline Transect Number & $\begin{array}{l}\text { Right angled distance by } \\
\text { observer, } L(\mathbf{k m})\end{array}$ & $\begin{array}{l}\text { Effective walked strip } \\
\text { width, W(km) }\end{array}$ & Number of Monkeys sighted, $\mathbf{N}$ & Animal Population Density \\
\hline 1 & 2.0 & 0.00 & 0 & 0 \\
\hline 2 & 2.0 & 0.00 & 0 & 0 \\
\hline 3 & 2.0 & 0.00 & 0 & 0 \\
\hline 4 & 2.0 & 0.00 & 0 & 0 \\
\hline 5 & 2.0 & 0.00 & 0 & 0 \\
\hline 6 & 2.0 & 0.00 & 0 & 0 \\
\hline 7 & 1.4 & 0.20 & 15 & 26 \\
\hline 8 & 2.0 & 0.05 & 0 & 0 \\
\hline 9 & 2.0 & 0.00 & 0 & 0 \\
\hline 10 & 2.0 & 0.00 & 0 & 0 \\
\hline
\end{tabular}

Table 2. Population Density of the Mona Monkeys in the Second Census.

Population density $=3 / \mathrm{km}^{2}$

The mean population densities of Mona monkeys in the study area are 4 individuals $/ \mathrm{Km}^{2}$ and 3 individuals $/ \mathrm{Km}^{2}$ for the first and second census respectively (Table 1 and Table 2). As shown in Table 1, the population density of Mona Monkeys in the first survey was 35 in one (1) large group of 20 animals sighted on transect number 8 , the observer having walked a right-angled distance of $1.9 \mathrm{~km}$ and at an effective strip width of $0.15 \mathrm{~km}$. Table 2 shows a population density of 26 in the second survey in another large group of fifteen (15) animals sighted on transect number 7 , the observer having walked a right angled distance of $1.4 \mathrm{~km}$ with an effective strip width of $0.20 \mathrm{~km}$ respectively.

During transect walks in the sanctuary, 30 spots of anthropogenic disturbances were recorded including evidence of hunting activities as indicated in fresh human footprints, clipping of shrubs, recently used and discarded empty shell cases of bullets. None of these areas recorded any presence of Mona Monkeys or any other wildlife species throughout field investigation.

The results also show that seven hundred and seventy eight (778) plants species belonging to twenty seven (27) families were enumerated. With pycnantus angolensis $(5.14 \%)$ having the highest incidence followed by Bailonella toxisperma $(4.50 \%)$ and Tetrapheura tetraptera $(3.86 \%)$. The least encountered plants species were those of Uapaca acuminate and Garcinia manii (0.26\%), followed by Cola lepidota, Elaies guineensis, Uapaca staudtii and Antrocaryon micraster (0.39\%).

\section{Discussions}

The mean population density of Mona monkeys in Afi Mountain Wildlife Sanctuary is: 


$$
\frac{4+3}{2}=3.5 \approx 4.0 \mathrm{~km}^{2}
$$

The statistical test of significance between the two population density means, showed no significant difference (P.cal. $0.229<$ P.tab. 2.10 at 0.05). From the two censuses, the overall density of Mona Monkeys in Afi Mountain Wildlife Sanctuary is $4 / \mathrm{km}^{2}$.

A mean population density of four (4) Mona Monkeys per square kilometer in Afi Mountain Wildlife Sanctuary is the same with that of four (4) individuals $/ \mathrm{km}^{2}$ of the Red-Eared and Putty-Nosed monkeys in the same study area as observed by [10]. It is also more than that of zero (0) White - Throated Monkeys in the same study area [11]. However, it is less than that of $14 / \mathrm{km}^{2}$ of the White - Throated monkeys observed by [6] in Okomu National Park. It is also less than that observed by [12] in Gashaka Gumti National Park. The Mona Monkeys of Afi Mountain Wildlife Sanctuary were observed in groups larger than usual for guenons. However, [13] as opined by [14] submitted that these large groups could be a fusion of more than one (1) group as a survival strategy. Although, the Mona monkey has been regarded as a weed species and often abundant [2], this study has shown that there can be an exception to that.Physical observations and indices of foot prints, calls, faeces and feeding places revealed the presence of diverse wildlife species in the study area. Reports of anthropogenic disturbances during the study period were also evidences of high hunting pressures that could put primate populations at low levels. This situation becomes more challenging considering the near absence of a systematic wildlife monitoring programme in the Sanctuary. Though there were no direct evidences of hunting, some traces of hunting activities in the Sanctuary and the surrounding areas were recorded including footprints of hunters, discarded empty shells and snares. Information was also gathered from some local people expressing their dismay over the level of hunting in the Sanctuary due to ineffective patrols. The people also enumerated some of the weapons used in killing primates in the Sanctuary which included wire snares being the most common tool used for killing the animals followed by shotguns, rifles and dane guns. The high rate of snares used to carry out these nefarious activities has also been reported by [15] where 2171 snares were removed during a survey of Gorillas in the study area. Studies by [16] reported declining population of drills in all the known habitats as a result of illegal hunting, habitat degradation and other forms of development by the local communities living around the study area. This has been aggravated by the landslide and flooding of $14^{\text {th }}$ July, 2012 which affected the forest in the Study Area with negative impacts on the population of primates [17]. Although, no demographic study has been conducted in the area on the immediate aftermath of the disaster, it is likely that the Mona Monkey population in the Sanctuary will definitely suffer depletion.
The result also shows that more plants species in less families were encountered in this survey than that by [18]. Furthermore, cash crop species in the study area include Musa paradiasica (3.21\%), Theobroma cacoa $(2.57 \%)$ and Musa sepientum (1.29\%). This observation is a strong indication that the study area is seriously affected by anthropogenic activities (Farming).

\section{Conclusion and Recommendations}

The population density of the Mona Monkeys in Afi Mountain Wildlife Sanctuary is $4 / \mathrm{km}^{2}$ due to the fact that this species was sighted directly during the survey of the wildlife sanctuary. And as indicated by the results, primates' populations in the study area as well as that of other animals may have been affected by adverse conditions. Apart from the Mona Monkeys, physical observation and other indices revealed the presence of diverse animalspecies.

Therefore, there is need to carry out research on the ecological requirements and biology of the numerous species, especially the endangered Cross River Gorillas and the Drill Monkeys in the study area. Government, NGOs and individuals should encourage research on these species through adequate logistics and financial support.

\section{References}

[1] Edet, D. I. (2011). Biodiversity utilization in Afi Mountain Wildlife Sanctuary. PhD Dissertation, Department of Fisheries and Wildlife, University of Ibadan. Pp 356.

[2] Oates, J. F. (2011). Primates of West Africa. A field guide and Natural History. Panamericana Formase impress, S. A., Bogota, Columbia. Pp.154-334.

[3] Eniang, E. A and Egwali, E. C. (2010). Conservation of Ophidian species in Tropical Moist Forest Zone of Akwa Ibom and Cross River State, Nigeria. In practical issues in Forest and Wildlife Resources Management. Ijeomah, H. M and Aiyeloja, A. A. (eds) Green Canopy Consultants, Choba, Port Harcourt, Nigeria. Pp 471-502.

[4] Lacher, T. E. (2003). Tropical Ecology, Assessment, and monitoring (TEAM) Initiative. Primate Monitoring Protocol. Conservation International. Washington D.C. Pp 2-10.

[5] Oates, J. F. (2001). Scientific knowledge of the Cross River Gorilla - A Historical Review. Proceedings of the Cross River Gorilla Calabar Nigeria, April 2001, P8.

[6] Ajayi, S., Edet, D. I. and Bukie, J. O. (2011). Population Density of the White-Throated Monkey (Cercopithecus erythrogaster) in Okomu National Park, Edo State, Nigeria. Journal of Agriculture, Forestry and the Social Sciences. Vol. 9, No. 2, Pp. 175-182.

[7] Peres, C. A. (1999). General Guidelines for standardizing line-transect surveys of TropicalForest Primates. Neotropical primates 7 (1): 11-16.

[8] Hall, J. B and Swaine, M. D. (1981). Distribution and Ecology of vascular plants in Tropical Rain Forest. W. Jink Publishers. Den Haag. Pp 53-55. 
[9] Wirkikfea, M. C., Agbelusi, E. A. and Afolayan, T. A. (2008). Population Density and MovementPatterns of the Forest Elephant (Loxodonta africana cyclotis) in Okomu National Park Edo State, Nigeria. Research for Development Forestry, Forest Products and Natural Resources Management. Editors. J.C. Onyekwelu, V. A. Adekunle and D. O. Oke. Proceedings of the first National Conference of the Forests and Forest Products Society. Federal University of Technology Akure, 16-18 ${ }^{\text {th }}$ April, 2008. Pp 216-222.

[10] Bukie, J. O. (2014). Some Aspects of the Population Ecology of Guenons in Afi Mountain Wildlife Sanctuary, Cross River State, Nigeria. Unpublished M. Sc. Thesis in the Department of Forestry and Wildlife Resources Management, University of Calabar, Calabar. 197Pp.

[11] Bukie, J. O., Ebu, V. T. and Nchor, A. A. Population Ecology of the White-Throated Monkeys(Cercopithecus erythrogaster) in Afi Mountain Wildlife Sanctuary (AMWS), Cross River State, Nigeria. International Journal of Agriculture and Forestry (2015), 5(4): 245-248.

[12] Dunn, A. (1993). Large mammals of Gashaka Gumti National Park, Nigeria: Line transects surveys from forest and savannah. Lagos: Federal Ministry of Agriculture, water resource and rural development, $72 \mathrm{pp}$.

[13] Ogunjemite, B. G., Ajayi, B., and Agbelusi, E. A. (2007).
Habitat structure of chimpanzeecommunities in Nigeria: a comparison of sites. Acta Zoological Sinica 53(4), 579-588.

[14] Glenn, M. E., Matsuda, R. and Bensen, K. J. (2002).Unique behavior of the Mona Monkey (Cercopithecus mona): Allmale group and copulation calls. In M.E. Glenn and M. Cords (Eds). The guenons: Diversity and Adaptation in African monkeys.

[15] Ettah, U. S. (2008). Conservation strategies of Cross River, Gorilla (Gorilla gorilla Diehli) in AfiMountain Wildlife Sanctuary of Cross River State Nigeria. An unpublished M. Sc Dissertation submitted to the Department of Forestry and Wildlife. University of Uyo, Uyo Nigeria. 65 p.

[16] Oates J. F. and Butynski, T. M. (2008). Mandrillus leucophaeus. In: IUCN 2008, IUCN Red List of Threatened Species.

[17] Ibiang, E. I. (2012). Report on Preliminary Investigations on the Environmental Damage (flood,erosion and landslide) that occur in the Afi Mountain Wildlife Sanctuary, Cross River State Forestry Commission.

[18] Daniel I. Edet, Henry M. Ijeomah and Augustine U. Ogogo (2012). Preliminary assessment of tree species diversity in Afi Mountain Wildlife Sanctuary, Southern Nigeria. Agric. Biol. J.N. America. 2012, 3 (12): 486-49. 